\title{
Conducting Business with God: Is God Blessing Islamic Banks with Better Financial Performance than Conventional Banks?
}

\author{
Musaed S. Alali \\ Assistant Professor, College of Business Studies, Department of Insurance and Banking \\ The Public Authority for Applied Education and Training (PAAET), Kuwait. \\ E-mail: ms.alali@paaet.edu.kw
}

Received: October 2, 2019 Accepted: October 30, 2019 Published: December 14, 2019

doi:10.5296/ifb.v6i2.16035 URL: http://dx.doi.org/10.5296/ifb.v6i2.16035

\begin{abstract}
This study aims to compare the financial performance between Islamic and conventional banks listed at Kuwait stock exchange over the period 2011-2018 using the modified DuPont model of financial analysis which is based on the analysis of return on equity (ROE). Unlike previous studies where researchers compared the performance on a bank-to-bank basis, this study examines the aggregate ratios of Islamic banks and compare it to aggregate ratios of conventional banks. The study also adds volatility into the model since consistency in returns indicated a more stable sector. Results obtained from this study showed that conventional banks in Kuwait had a better mean performance during the study period in terms of both return on assets (ROA) and return in equity (ROE), Islamic banks also showed a higher deviation in these two ratios resulting in a lower Sharpe ratio. While the results showed no statistically significant mean difference between Islamic and conventional banks in terms of return on assets (ROA), the results also showed a statistically significant difference in mean return on equity (ROE) between the two sub-sectors. On the other hand, Islamic banks showed an impressive improvement in their ratios during the last three years of the study period which impose a real threat to conventional banks in the future.
\end{abstract}

Keywords: Modified DuPont model, Islamic banks, Return on equity, Net profit margin, Equity multiplier, Return on Assets, Volatility, Sharpe ratio, Kuwait stock exchange (KSE) 


\section{Introduction}

There has always been a huge debate between scholars on whether or not Islamic banks have a better financial performance than conventional banks. As a result a massive amount of literature comparing the financial performance between Islamic and conventional banking was produced using numerous models. In practice, both Islamic and conventional banks provide their customers with more or less the same products, the main difference is that Islamic banks work under Shari'a law (Islamic law) that prohibits the use of interest. Both entities still have a common goal which is maximizing the wealth of their shareholders.

Many comparative studies between Islamic and conventional banks were conducted. Iqbal (2001) evaluated the performance of Islamic banks through trend analysis and ratios analysis during the period from 1990 to 1998. He found that Islamic banks performed better than the conventional banks over the specified period of time. Jaffar and Manarvi (2011) evaluated the performance of Islamic and conventional banks using CAMEL framework using the data of 5 Islamic and 5 conventional banks over the period of 2005 to 2009. They concluded that Islamic banks performed better and having high liquidity than the conventional banks, moreover they realized that conventional banks were pioneer in the management and had a good earning ability. Viverita (2011) studied Islamic banks in Indonesia over the period 2004 to 2008 and concluded that Islamic banks observed insignificant cost efficiency at $5 \%$ than conventional banks. It was also found that Islamic banks generated more profitability and revenue than conventional banks. Majid et al. (2003) examined the cost efficiency of 34 commercial banks in Malaysia and showed that the efficiency of Islamic banks is not statistically different from the conventional banks. On the other hand, Ashraf and Rehman (2011) conducts a study on both of Islamic and conventional banks in Pakistan and concluded that Islamic banks were less effective than the conventional banks. Other studies like Saaid et al. (2003) and Kabir Hassan (2005) also conclude that Islamic banking industry is relatively less efficient compared to their conventional counterparts. Olson and Zoubi (2008) used 26 financial ratios to compare Islamic and conventional banks in the GCC countries over the period 2000 to 2005 and concluded that Islamic banks are less efficient and operating with greater risk compared to conventional banks.

DuPont model is a popular model used by both researchers and practitioners in evaluating the financial performance of banks and companies. Sheela and Karthiikeyan (2012) used DuPont model to evaluate the financial performance for the top three pharmaceutical companies in India over the period 2002 to 2012 . Their results showed that during their study period Cipla pharmaceutical had the highest return on assets (ROA) and return on equity (ROE) among the companies under study. Collier et al. (2010) applied DuPont model in evaluating the financial performance of AFFIN bank in Malaysia for the period 1999 to 2006 and the effect of rapid economic environment changes on its financial performance. They concluded that AFFIN bank needed a recovery period of four years (1999-2002) after the Asian financial crisis of 1997-1998. It was not until the year 2002 that the bank started having a steady financial performance. Almazari (2012) evaluated the financial performance of Jordanian Arab bank using modified DuPont model over the period 2000 to 2009. He concluded that the Jordanian Arab bank had a relatively steady financial performance with return on equity (ROE) ratio of 
$12.01 \%$ over the period 2000 to 2008 , but due to the global financial crisis the ratio went down to $6.58 \%$ in the year 2009 .

\section{Method}

DuPont recognized the relation between one profitability ratio which is net profit margin (NPM) and an efficiency ratio which is total asset turnover (TAT), and return on assets (ROA). The product of the net profit margin (NPM) and the total asset turnover (TAT) equals return on assets (ROA), and that was the original DuPont model, as illustrated in Equation 1 below.

$\mathrm{ROA}=(\mathrm{NPM}) \times(\mathrm{TAT})$

Where;

Net Profit margin $($ NPM $)=$ Net Income / Total Revenues

Total Assets Turnover $(\mathrm{TAT})=$ Total Revenues / Total Assets

The DuPont model was modified to include the ratio of total assets to equity (equity multiplier (EM)) to calculate ROE, since ROE is the product of return on assets (ROA) by equity multiplier (EM). Little, et al (2009), stated that the modified DuPont model of financial ratio analysis is used to identify the drivers of financial success under alternative business strategies. A financial analysis model for financial institutions which is based on the DuPont system of financial analysis return on equity model was constructed by Saunders (2000). He used three components in determining the return on equity (ROE), these three components were net profit margin (NPM), total assets turnover (TAT), and equity multiplier (EM). The net profit margin (NPM) evaluates the components of the income statement, while the total assets turnover (TAT) evaluates the assets side of the balance sheet and the equity multiplier (EM) analyses the liabilities and the shareholders equity side of the balance sheet. Return on equity (ROE), is first decomposed into return on asset (ROA) and the equity multiplier (EM). Return on assets is determined net profit margin (NPM) and total asset turnover (TAT).

The modified DuPont modified model is shown in Equations 4 and 5 below.

$\mathrm{ROE}=(\mathrm{ROA}) \times(\mathrm{EM})$

Or $\mathrm{ROE}=(\mathrm{NPM}) \times(\mathrm{TAT}) \times(\mathrm{EM})$

Where;

Equity Multiplier $(\mathrm{EM})=$ Total Assets / Equity

The net profit margin ratio is an indicator to how effective a bank is in controlling its costs. The higher the ratio, the more effective the bank is at converting revenues into profit. Total assets turnover (TAT) ratio shows the assets utilization of the bank, which means how much revenue generated for every Kuwaiti dinar of assets the bank has. The higher the ratio the 
more efficient the bank is in utilizing his assets. The equity multiplier (EM) is a measure of how leverage the bank is. One of the most important profitability metrics is return on equity (ROE). Return on equity (ROE) reveals how much profit a company earned in comparison to the total amount of shareholder equity found on the balance sheet.

Ignoring the effect of volatility might result in a misleading results and for that Sharpe ratio is used in this research in order to measure the effect of volatility on returns. The Sharpe ratio measures the effect of volatility on the return, Burnside et al. (2011) calculated the Sharpe ratio as;

$S R=\frac{\bar{\pi}}{S D}$

Where SR is the Sharpe ratio, $\bar{\pi}$ is the mean return and SD is the standard deviation. A modification is made to this formula by substituting the mean return with return on assets (ROA) and return on equity ratio (ROE), which would result in,

$$
\begin{aligned}
& S R_{R O A}=\frac{\overline{R O A}}{S D} \\
& S R_{R O E}=\frac{\overline{R O E}}{S D}
\end{aligned}
$$

\section{Data and Empirical Results}

This study aims to compare the financial performance between Islamic and conventional banking sub-sectors in Kuwait over the period 2011 to 2018. The data are the aggregate financial numbers of five Islamic and five conventional banks listed at Kuwait stock exchange. The data for this study were obtained from Kuwait institute of banking studies website.

\begin{tabular}{|c|c|c|c|c|c|c|c|c|c|c|c|}
\hline Islamic banks & 2011 & 2012 & 2013 & 2014 & 2015 & 2016 & 2017 & 2018 & & & \\
\hline Total Income & 1947.642 & 2079.027 & 2254.335 & 2354.742 & 2348.735 & 2317.168 & 2562.738 & 2775.595 & & & \\
\hline $\begin{array}{l}\text { Net profit for the } \\
\text { year }\end{array}$ & 78.421 & 182.162 & 214.220 & 248.840 & 255.055 & 283.299 & 334.537 & 403942 & & & \\
\hline Total assets & 18879.276 & 20693.826 & 22553.975 & 25684.153 & 26098.026 & 26646.313 & 28684.541 & 30390.373 & & & \\
\hline Total equity & 2296.101 & 2440.409 & 2863.891 & 3070.144 & 3077.207 & 3257.433 & 3476.917 & 3599.064 & & & \\
\hline $\begin{array}{l}\text { Net Profit Margin } \\
\text { (NPM) } \\
\text { Total Assets }\end{array}$ & $4.03 \%$ & $8.76 \%$ & $9.50 \%$ & $10.57 \%$ & $10.86 \%$ & $12.23 \%$ & $13.05 \%$ & $14.55 \%$ & & & \\
\hline $\begin{array}{l}\text { Turnover (TAT) } \\
\text { Equity Multiplier }\end{array}$ & $10.32 \%$ & $10.05 \%$ & $10.00 \%$ & $9.17 \%$ & $9.00 \%$ & $8.70 \%$ & $8.93 \%$ & $9.13 \%$ & & & \\
\hline $\begin{array}{l}\text { (EM) } \\
\text { Return on Assets }\end{array}$ & 8.22 & 8.48 & 7.88 & 8.37 & 8.48 & 8.18 & 8.25 & 8.44 & SD & Average & SR \\
\hline $\begin{array}{l}\text { (ROA) } \\
\text { Return on Equity }\end{array}$ & $0.42 \%$ & $0.88 \%$ & $0.95 \%$ & $0.97 \%$ & $0.98 \%$ & $1.06 \%$ & $1.17 \%$ & $1.33 \%$ & $0.27 \%$ & $0.97 \%$ & $3.65 \%$ \\
\hline$(\mathrm{ROE})$ & $3.42 \%$ & $7.46 \%$ & $7.48 \%$ & $8.11 \%$ & $8.29 \%$ & $8.70 \%$ & $9.62 \%$ & $11.22 \%$ & $2.24 \%$ & $8.04 \%$ & $3.59 \%$ \\
\hline $\begin{array}{l}\text { Conventional } \\
\text { banks }\end{array}$ & 2011 & 2012 & 2013 & 2014 & 2015 & 2016 & 2017 & 2018 & & & \\
\hline Total income & 2457.824 & 2758.001 & 2807.484 & 2838.086 & 3046.722 & 3241.196 & 3509.297 & 3887.758 & & & \\
\hline
\end{tabular}

Table 1. Modified DuPont Financial Model 


\section{Macrothink}

Net profit for the

443.493

\section{$432.318 \quad 371.203$}

450.49

474.077

475.011

515.502

595.287

$\begin{array}{lllllllll}28859.562 & 32674.222 & 36403.667 & 40598.308 & 41747.609 & 42559.381 & 44606.424 & 47138.383\end{array}$

Total equity

4315.572

4642.153

4871.33

5377.284

5606.364

5794.525

6040.061

6434.269

Net Profit Margin

(NPM)

$18.04 \%$

$15.68 \%$

$13.22 \% \quad 15.87 \%$

$15.56 \% \quad 14.66 \%$

$14.69 \%$

$15.31 \%$

Turnover (TAT)

Equity Multiplier

(EM)

$8.52 \%$

$8.44 \%$

$7.71 \%$

$6.99 \%$

$7.30 \% \quad 7.62 \%$

$7.87 \%$

$8.25 \%$

$\begin{array}{lll}6.69 & 7.04 & 7.47\end{array}$

7.55

7.45

7.34

7.39

7.33

SD

Average

SR

(ROA)

$1.54 \%$

$1.32 \% \quad 1.02 \%$

$1.11 \%$

$1.14 \%$

$1.12 \%$

$1.16 \%$

$1.26 \%$

$0.16 \% \quad 1.21 \%$

$7.41 \%$

$10.28 \% \quad 9.31 \% \quad 7.62 \%$

$8.38 \% \quad 8.46 \%$

$8.20 \%$

$8.53 \%$

$9.25 \%$

$0.82 \% \quad 8.75 \%$

Net profit margin (NPM) is a ratio that measures the efficiency of the bank in converting their income into profit. From table (1) it can be seen that conventional banks were, on average, more efficient in converting their income into profit. While Islamic banks were able to convert only $10.44 \%$ of their income into net profit, conventional banks were able to convert $15.38 \%$. When looking at the trend line in figure (1) it can be seen that Islamic banks are showing an upward trend while conventional banks are having an almost flat trend line. This would indicate that Islamic banks are improving their methods in converting their income to profit more than conventional banks. By looking at the volatility of NPM, it can be seen that Islamic banks have a higher standard deviation and that logical since Islamic banks are showing growth in that ratio while conventional banks are showing a steady ratio over the study period.



Figure 1. Net Profit Margin (NPM)

Total assets turnover (TAT) is a ratio that measures the ability of the banks in utilizing their assets to generate income. It is an efficiency ratio of the bank. Results show that Islamic 


\section{Macrothink}

banks were more efficient in utilizing their assets than conventional banks. Islamic bank were able, during the study period, to achieve a revenue to assets ratio of $9.41 \%$ compared to $7.84 \%$ for conventional banks. With Islamic banks achieving more revenues on their assets than conventional banks, they were unable to convert that advantage to profit which makes them less cost efficient than conventional banks.

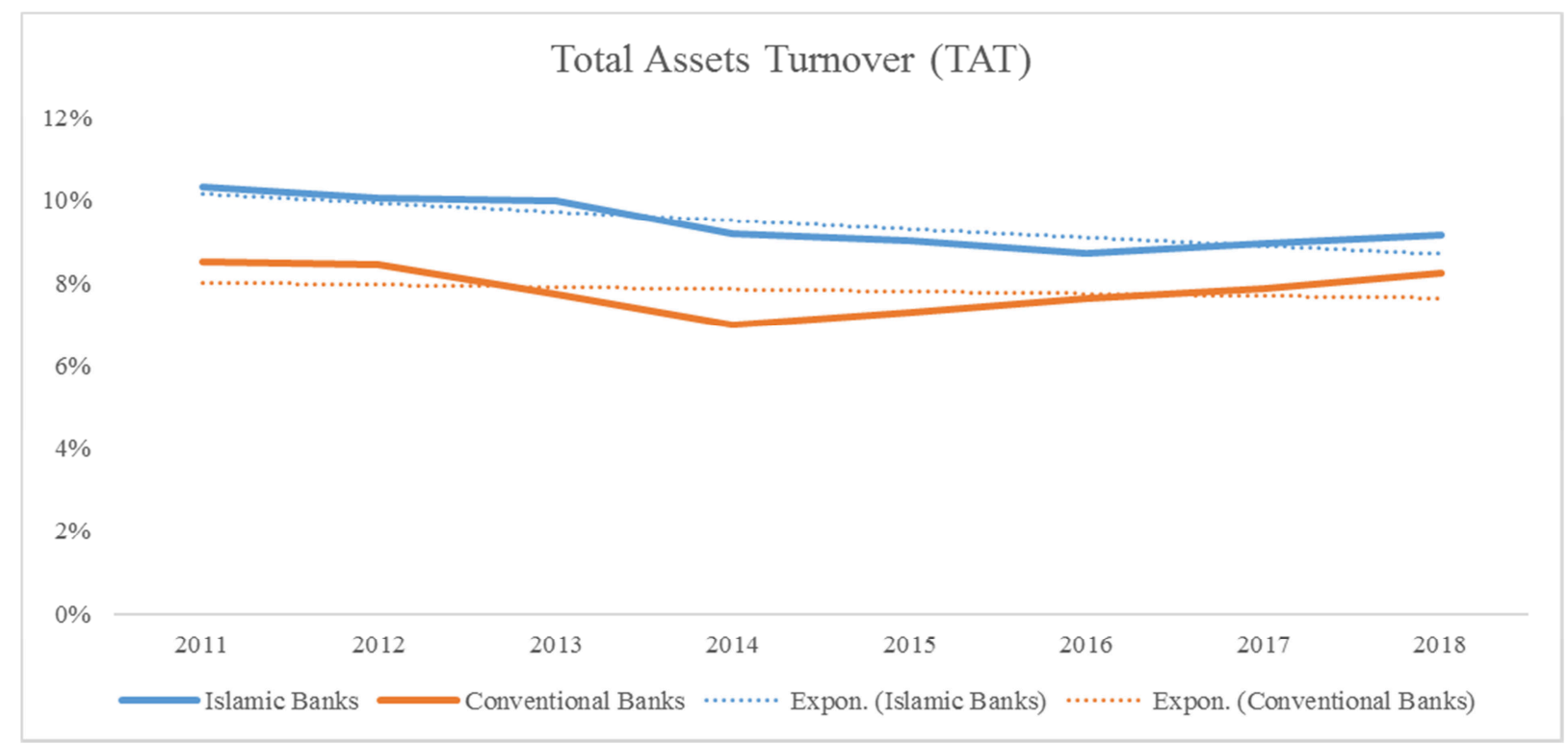

Figure 2. Total Assets Turnover (TAT)

Equity multiplier (EM) is a measures of bank leverage. On an average Islamic banks had total assets that was 8.29 times their equity while conventional banks were running a 7.28 time leverage. This would indicate that Islamic banks are more aggressive in their business, but having a high leverage is a two bladed sword while it increases the bank's profitability during good financial periods it would have a catastrophical effect during financial distress periods. Adapting a high leverage policy by Islamic banks was one of the reasons that these banks were more effected by the 2008 financial crisis than conventional banks. 


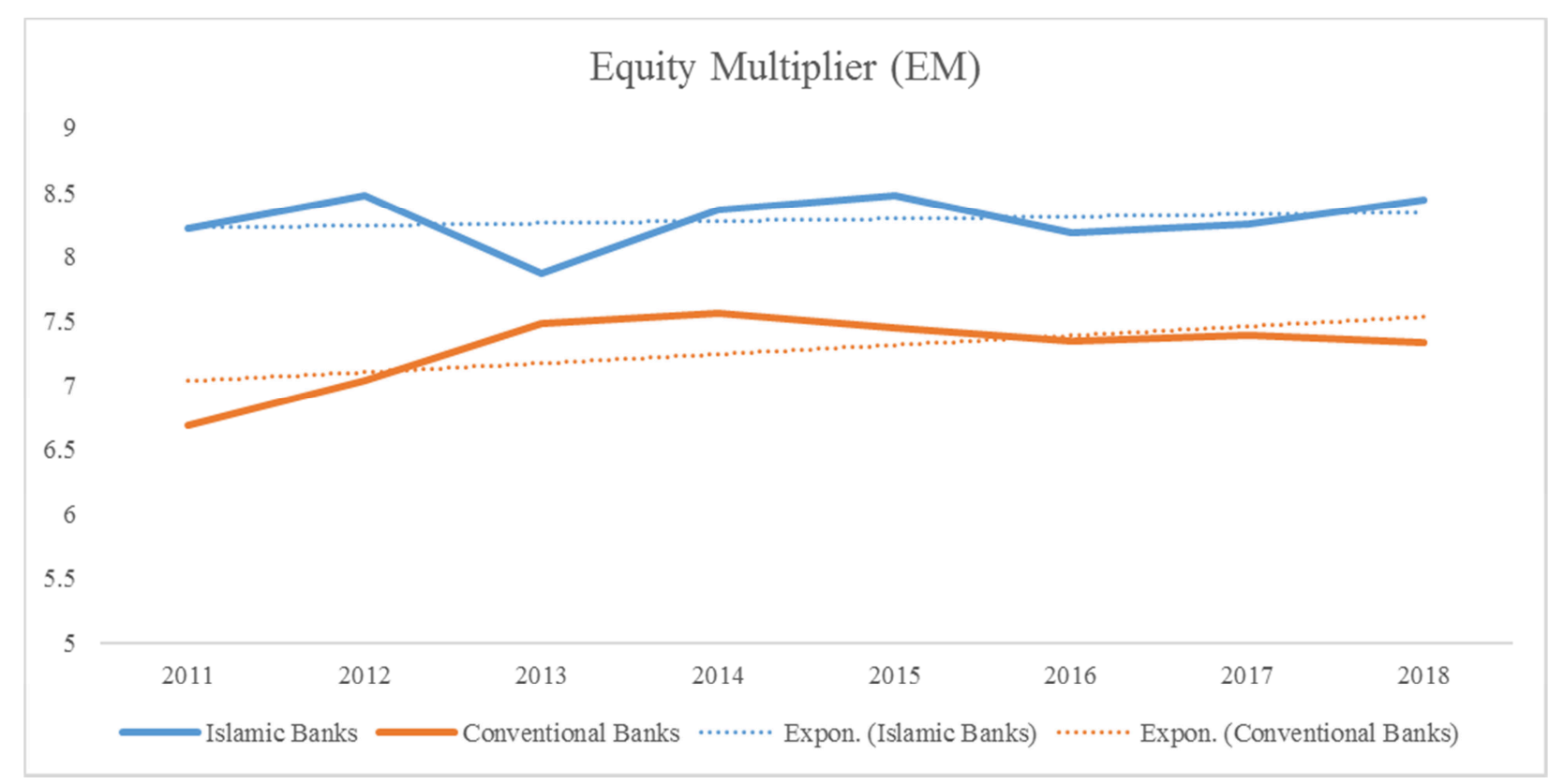

Figure 3. Equity Multiplier (EM)

The original DuPont model had return on assets (ROA) are the main target for the model. On an average, conventional banks achieved a ROA ratio of $1.21 \%$ compared to $0.97 \%$ for Islamic banks. But during the last two years of the study period Islamic banks produced a higher ROA ratio than conventional banks. As seen from figure (4), Islamic banks are showing an upward trend in that ratio while conventional banks are showing a downward trend. Islamic banks showed a high standard deviation in that ratio which might indicate some level of uncertainty in maintaining such growth. When taking the effect of the volatility of that ratio into consideration in calculating the Sharpe ratio, it can be seen that Islamic banks produced a Sharpe ratio of $3.65 \%$ compared to $7.41 \%$ for conventional banks that had a less volatility. 


\section{Macrothink}



Figure 4. Return on Assets (ROA)

When examining mean difference between Islamic and conventional bank in terms of return on assets (ROA) using the t-test, it can be seen from table (2) that there was no significant difference between the banks since the $P$-value is lower than the confidence level of 0.05 . In terms of variance, results show that the $F$-critical was higher than the $F$-value which means that Islamic and conventional banks had an equal variance.

Table 2. $t$-test and $F$-test results (ROA)

\begin{tabular}{llllll}
\hline \multirow{2}{*}{ t-Test: Two-Sample Assuming Equal Variances } & \multicolumn{4}{l}{ F-Test Two-Sample for Variances } \\
& ROA & ROA & & ROA Islamic & ROA Con \\
\hline Islamic & Con & & 0.0097 & 0.0121 \\
Mean & 0.0097 & 0.0121 & Mean & 0.0000 & 0.0000 \\
Variance & $7.0 \mathrm{E}-06$ & 0.0000 & Variance & 8 & 8 \\
Observations & 8 & 8 & Observations & 7 & 7 \\
Pooled Variance & $4.8 \mathrm{E}-06$ & & df & & \\
Hypothesized Mean & 0 & & F & 2.648 & \\
Difference & 14 & & P(F<=f) one-tail & 0.111 & \\
$\mathrm{df}$ & -2.169 & & F Critical one-tail & 3.787 & \\
$\mathrm{t}$ Stat & 0.024 & & & & \\
$\mathrm{P}(\mathrm{T}<=\mathrm{t})$ one-tail & 1.761 & & & & \\
$\mathrm{t}$ Critical one-tail & 0.048 & & & & \\
$\mathrm{P}(\mathrm{T}<=\mathrm{t})$ two-tail & 2.145 & & & & \\
$\mathrm{t}$ Critical two-tail & & & & & \\
\hline
\end{tabular}




\section{Macrothink}

In the 1970's the interest of financial managers shifted from return on assets (ROA) to return on equity (ROE) and making the maximization of the shareholders wealth their ultimate target. This shift led to the modification of the original DuPont model and return on equity (ROE) became the final output of the model. Again on an average conventional banks produced a higher return on equity (ROE) than Islamic banks producing a mean ROE ratio of $8.75 \%$ compared to $8.04 \%$ for Islamic banks, but over the last three years of the study period Islamic banks produced a better ROE ratio than conventional banks. When taking the volatility into account, Islamic banks produced a Sharpe ratio of $3.59 \%$ compared to $10.62 \%$ for conventional banks.

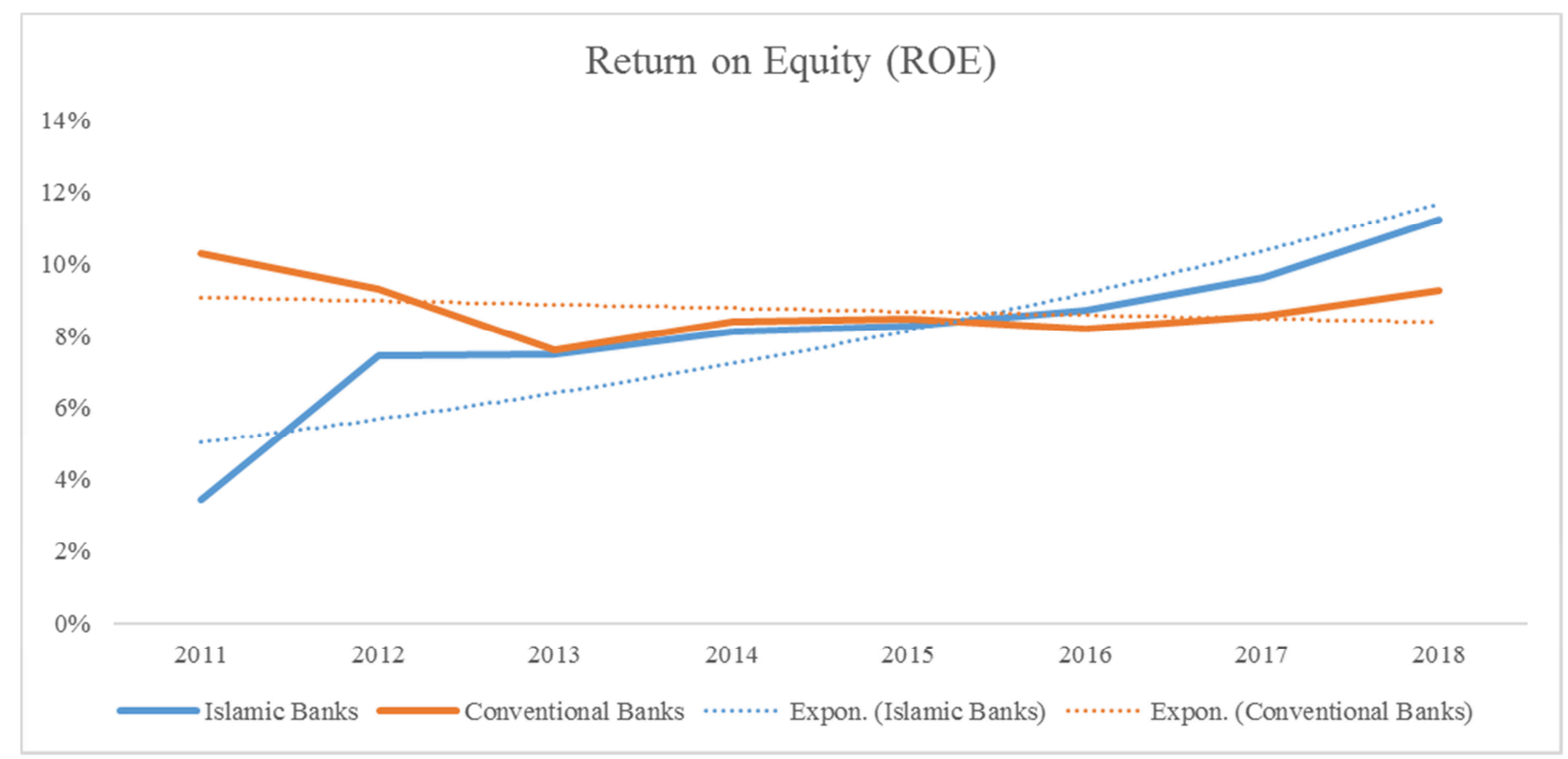

Figure 5. Return on Equity (ROE)

By looking at table (3) it can be seen that when it comes to mean difference the results shows a $P$-value of 0.4103 which is higher than the 0.05 and for that it can be concluded that there is a significant difference in return on equity (ROE) mean between Islamic and conventional banks at the $95 \%$ confidence level. In terms of variance the results show that there is an unequal variance between the return on equity (ROE) of Islamic banks and conventional banks. 


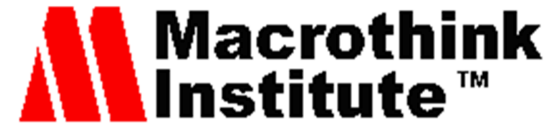

Table 3. $t$-test and $F$-test results (ROE)

$\mathrm{t}$-Test: Two-Sample Assuming Equal Variances

F-Test Two-Sample for Variances

\begin{tabular}{|c|c|c|c|c|c|c|}
\hline & & $\begin{array}{l}\text { ROE } \\
\text { Islamic }\end{array}$ & $\begin{array}{l}\text { ROE } \\
\text { Con }\end{array}$ & & ROE Islamic & ROE Con \\
\hline Mean & & 0.0804 & 0.0875 & Mean & 0.0804 & 0.0875 \\
\hline Variance & & 0.0005 & 0.0001 & Variance & 0.0005 & 0.0001 \\
\hline Observations & & 8 & 8 & Observations & 8 & 8 \\
\hline $\begin{array}{l}\text { Pooled Variance } \\
\text { Hypothesized }\end{array}$ & Mean & 0.0003 & & $\mathrm{df}$ & 7 & 7 \\
\hline Difference & & 0 & & $\mathrm{~F}$ & 7.4001 & \\
\hline $\mathrm{df}$ & & 14 & & $\mathrm{P}(\mathrm{F}<=\mathrm{f})$ one-tail & 0.0085 & \\
\hline t Stat & & -0.8486 & & F Critical one-tail & 3.7870 & \\
\hline $\mathrm{P}(\mathrm{T}<=\mathrm{t})$ one-tail & & 0.2052 & & & & \\
\hline t Critical one-tail & & 1.7613 & & & & \\
\hline $\mathrm{P}(\mathrm{T}<=\mathrm{t})$ two-tail & & 0.4104 & & & & \\
\hline t Critical two-tail & & 2.1448 & & & & \\
\hline
\end{tabular}

\section{Discussion}

This study was conducted to compare the financial performance between Islamic and conventional banks listed at Kuwait stock exchange over the period 2011 to 2018. Results obtained from this study showed that, over the study period, conventional banks had a better financial performance than Islamic banks in terms of average return on assets (ROA) and average return on equity (ROE). The results also revealed that Islamic banks had a higher volatility in these two parameters resulting in a lower Sharpe ratio. While Islamic banks underperformed conventional banks during the study period, Islamic banks have demonstrated huge improvement in their ROA and ROE ratios in the last three years compared to conventional banks which makes them more likely to gain more market share in the near future if they continue at the same bass.

\section{References}

Almazari, A. (2012). Financial Performance Analysis of the Jordanian Arab Bank by Using the DuPont System of Financial Analysis. International Journal of Economics and Finance, 4(4), 86-94. https://doi.org/10.5539/ijef.v4n4p86

Burnside, C., Eichenbaum, M., Kleshchelski, I., \& Rebelo, S. (2011a). Do Peso Problems Explain the Returns to the Carry Trade? Review of Financial Studies, 24, 853-891. https://doi.org/10.1093/rfs/hhq138

Collier, H., McGowan, C., \& Muhammad, J. (2010). Evaluating the Impact of a Rapidly Changing Economic Environment on Bank Financial Performance Using the DuPont System of Financial Analysis. Asia Pacific Journal of Finance and Banking Research, 4(4), 25-35.

Iqbal, M. (2001). Islamic and Conventional Banking in the Nineties: A Comparative Study. Islamic Economic Studies, 8(2), 1-28. 
Jaffar, M., \& Manarvi, I. (2011). Performance Comparison of Islamic and Conventional Banks in Pakistan. Global Journal of Management and Business Research, 11(1), 59-66.

Kabir, H. M. (2005). The cost, profit and X-efficiency of Islamic banks, working paper. In Proceeding of the Economic Research Forum 12th annual conference. Cairo, Egypt.

Little, P. L., Mortimer, J. W., Keene, M. A., \& Henderson, L. R. (2009) Evaluating the effect of recession on retail firms' strategy using DuPont method: 2006-2009. Journal of Finance and Accountancy, 7, 1-7.

Majid, M. A., Nor, N. G., \& Said, F. F. (2003). Efficiency of banks in Malaysia (vol. 2, pp. 405-416). In Proceedings of the fifth international conference on Islamic Economics and Finance (Bahrain).

Olson, D., \& Zoubi, T. (2008). Using Accounting Ratio to Distinguish between Islamic and Conventional Banks in the GCC Region. The International Journal of Accounting, 43(1), 4565. https://doi.org/10.1016/j.intacc.2008.01.003

Prendergast, P. (2006). Financial analysis: how a "modified DuPont approach" to ratio analysis can be used to drill down to the true cause of financial performance problems. Financial Management, May, 8, 48-49.

Saunders, A. (2000) Management of financial institutions (3rd ed.). McGraw Hill.

Sheela, C. C., \& Kerthikeyan, K. (2012). Financial Performance of Pharmaceutical Industry in India using DuPont Analysis. European Journal of Business and Management, 4(14), 8491.

Viverita. (2011). Performance Analysis of Indonesian Islamic and Conventional Banks. Retrieved from http://ssrn.com/abstract=1868938 dated 22.09.2011

\section{Copyrights}

Copyright for this article is retained by the author(s), with first publication rights granted to the journal.

This is an open-access article distributed under the terms and conditions of the Creative Commons Attribution license (http://creativecommons.org/licenses/by/4.0/). 